\title{
Systematic Review and Meta-Analysis: Relationships Between Attention-Deficit/Hyperactivity Disorder and Daytime Urinary Symptoms in Children
}

Author Name(s): Behrang Mahjani $(\mathrm{PhD})^{\mathrm{a}, \mathrm{b}, \mathrm{c}, \mathrm{g}}$, Lotta Renström Koskela (MD) ${ }^{\mathrm{i}}$, Christina Gustavsson Mahjani $(\mathrm{MS})^{\mathrm{a}, \mathrm{b}, \mathrm{c}}$, Magdalena Janecka $(\mathrm{PhD})^{\mathrm{a}, \mathrm{b}}$, Anita Batuure $(\mathrm{BS})^{\mathrm{a}, \mathrm{g}}$, Christina M. Hultman $(\mathrm{PhD})^{\mathrm{c}}$, Abraham Reichenberg $(\mathrm{PhD})^{\mathrm{a}, \mathrm{b}}$, Joseph D. Buxbaum $(\mathrm{PhD})^{\mathrm{a}, \mathrm{b}, \mathrm{c}, \mathrm{d}, \mathrm{e}, \mathrm{f}}$, Olof Akre (MD) ${ }^{\mathrm{i}, \mathrm{j}}$, Dorothy E. Grice $(\mathrm{MD})^{\mathrm{a}, \mathrm{b}, \mathrm{f}, \mathrm{g}, \mathrm{h}}$

\section{Affiliations}

a) Department of Psychiatry, Icahn School of Medicine at Mount Sinai, New York, NY, USA; b) Seaver Autism Center for Research and Treatment, Icahn School of Medicine at Mount Sinai, New York, NY, USA; c) Department of Medical Epidemiology and Biostatistics, Karolinska Institutet, Stockholm, Sweden; d) Department of Genetics and Genomic Sciences, Icahn School of Medicine at Mount Sinai, New York, NY, USA; e) Department of Neuroscience, Icahn School of Medicine at Mount Sinai, New York, NY, USA; f) The Mindich Child Health and Development Institute, Icahn School of Medicine at Mount Sinai, New York, NY, USA; g) Division of Tics, Obsessive-Compulsive Disorder (OCD) and Related Disorders, Icahn School of Medicine at Mount Sinai, New York, NY, USA; h) Friedman Brain Institute, Icahn School of Medicine at Mount Sinai. New York, NY, USA; i) Department of Molecular Medicine and Surgery, Karolinska Institutet, Stockholm, Sweden; j) Department of Pelvic Cancer, Karolinska Institutet, Stockholm, Sweden.

Correspondence: Dorothy E. Grice, M.D., Dorothy.Grice@ mssm.edu, 1425 Madison Avenue, New York, NY 10029, phone: 212-659-1670. 
medRxiv preprint doi: https://doi.org/10.1101/2020.08.28.20183541; this version posted September 1, 2020. The copyright holder for this preprint (which was not certified by peer review) is the author/funder, who has granted medRxiv a license to display the preprint in perpetuity.

It is made available under a CC-BY-NC-ND 4.0 International license .

\begin{abstract}
:
Lower urinary tract symptoms (LUTS), e.g., urinary frequency, pressure, urgency, and overactive bladder syndrome, are commonly reported in children with attention-deficit/hyperactivity disorder (ADHD). Understanding the co-occurrence of these conditions has implications regarding clinical approaches, treatments, and improved quality of life. We conducted a systematic review and meta-analysis to examine the relationships between LUTS and ADHD in children.

We searched for articles published between January 1990 and July 2019, in PubMed, CENTRAL, and PsycNet. Two authors independently screened all articles and extracted data. We performed random-effect meta-analyses for ADHD with pooled outcomes for LUTS.

We identified 117 relevant articles in the literature and 17 articles fulfilled the inclusion criteria for the systematic review, of which, 5 articles had sufficient data for meta-analysis. Examining ADHD among individuals with LUTS, the odds ratio was 2.99 (95\% CI: 1.13,7.88, P < 0.001), compared to controls. In multiple studies, the mean overall score for LUTS, using a standardized measure, was significantly higher in patients with ADHD in comparison to controls, and the severity of ADHD was positively associated with the severity of LUTS. Younger age in children was correlated with a higher LUTS score. Different subtypes of urinary incontinence demonstrated differences in behavioral problems and psychiatric comorbidity. Sex differences in LUTS were not consistent across articles.

Our results indicate clinically significant associations between ADHD and LUTS in children. Because LUTS and ADHD are common disorders in children, clinicians should be aware of these associations as they inform optimal assessment and treatment strategies.
\end{abstract}

Keywords: attention-deficit/hyperactivity disorder, lower urinary tract symptoms, overactive bladder 


\section{Declarations}

Funding: This study was supported by a grant from the Beatrice and Samuel A. Seaver Foundation (DEG, MJ, JDB, BM); the Mindworks Charitable Lead Trust (DEG); the Stanley Center for Psychiatric Research (DEG).

Conflicts of interest/Competing interests: The authors declare that they have no conflicts of interest.

Availability of data and material: Data are available in the literature and are also from the authors upon request.

Code availability: Open access software was used for the analysis.

Author Contributions: Mahjani had full access to all the data in the study and takes responsibility for the integrity of the data and the accuracy of the data analysis.

Study concept and design: Akre, Batuure, Buxbaum, Grice, Gustavsson Mahjani, Janecka, Koskela, Mahjani

Acquisition, analysis, or interpretation of data: Akre, Buxbaum, Grice, Janecka, Koskela, Mahjani

Drafting of the manuscript: Batuure, Buxbaum, Grice, Gustavsson Mahjani, Janecka, Koskela, Mahjani

Critical revision of the manuscript for important intellectual content: All authors.

Statistical analysis: Mahjani

Obtained funding: Grice

Study supervision: Akre, Buxbaum, Grice, Koskela 
medRxiv preprint doi: https://doi.org/10.1101/2020.08.28.20183541; this version posted September 1, 2020. The copyright holder for this preprint (which was not certified by peer review) is the author/funder, who has granted medRxiv a license to display the preprint in perpetuity.

It is made available under a CC-BY-NC-ND 4.0 International license .

\section{Introduction}

Attention-deficit/hyperactivity disorder (ADHD) is one of the most commonly diagnosed psychiatric disorders in children [1]. Approximately 5-9.4\% of children are diagnosed with ADHD, with a higher prevalence of the disorder in males than females $[1,2]$. The core diagnosis requires ongoing patterns of behavior that represent inattention and/or hyperactivity-impulsivity and interfere with development or expected functioning [3]. However, ADHD is often comorbid with other psychiatric disorders [4, 5] and medical conditions. Comorbidity with lower urinary tract symptoms $[6,7]$ and overactive bladder syndrome $[8,9]$ has been reported.

Lower urinary tract symptoms (LUTS) is a term that covers symptoms (e.g., storage, voiding, postmicturition, pain) that result from conditions affecting the bladder and urethra. Storage symptoms manifest as urinary urgency, frequency, nocturia, or incontinence. Incontinence can be divided into daytime incontinence and nighttime incontinence (i.e., enuresis). Daytime incontinence includes urge incontinence, stress incontinence, and mixed incontinence [10]. The population frequency of LUTS in children is between 9-40\%, and varies due to definitions and subcategories of LUTS [11, 12]. Overactive bladder syndrome $(\mathrm{OAB})$ is a symptom-based clinical diagnosis and is characterized by excessive urgency and frequency of urination. $\mathrm{OAB}$ has a prevalence of 5-12\% in children, and at least a third of affected children continue into adulthood with similar complaints [13]. LUTS and OAB have significant adverse effects on the overall quality of life. They can affect children's social and emotional development and increase risk for social isolation and teasing.

To date, no meta-analyses of associations between ADHD and LUTS have been published. We hypothesize that there is a clinically significant association between ADHD and lower urinary tract symptoms. Understanding the association between these two disorders is expected to have a positive impact on patient quality of life by providing the foundation for early preventive interventions, which is currently lacking, and more nuanced treatments. Therefore, we conducted a systematic review and meta-analysis to explore this association. 
medRxiv preprint doi: https://doi.org/10.1101/2020.08.28.20183541; this version posted September 1, 2020. The copyright holder for this preprint (which was not certified by peer review) is the author/funder, who has granted medRxiv a license to display the preprint in perpetuity.

It is made available under a CC-BY-NC-ND 4.0 International license .

\section{Methods}

\subsection{Search strategy and selection criteria}

We followed the PRISMA protocol [14] and registered our approach in PROSPERO [15] (ID= CRD42019118607). Figure 1 illustrates our search strategy to find the qualifying articles, which includes identification, screening, and eligibility. Identification We identified all articles with results in humans that included our search terms referencing ADHD or LUTS in the title, and ADHD and LUTS in the title or abstract; Screening At least two of the authors (BM, MJ, AB) independently screened all articles based on titles and abstracts (see below for the exclusion criteria). Twenty articles were randomly chosen and rescreened by a different author (DG), as a quality control measure; Eligibility At least two of the authors $(\mathrm{CM}, \mathrm{AB}, \mathrm{BM})$ independently reviewed the full text of the articles that passed screening. Excluded articles and reviewer conflicts were assessed independently by a different author. Twenty articles were randomly chosen and re-screened by a different author (DG). We used DistillerSR (Evidence Partners, Ottawa, Canada) software for screening the articles. For LUTS outcomes, we included overactive bladder, bladder pain syndrome, and daytime incontinence. We included all diagnoses and symptoms, even where the specific reference to ICD/DSM was missing, provided a standardized measure was used in the study.

We systematically searched for articles in PubMed, CENTRAL, PsycNet, and Google Scholar. Specific search terms used for PubMed search were: ((urinary) OR (lower urinary tract) OR (overactive bladder) OR (bladder pain syndrome) OR (incontinence)) AND (attention deficit hyperactivity) AND (urinary[Title] OR lower urinary tract[Title] OR overactive bladder[Title] OR bladder pain syndrome[Title] OR incontinence[Title] OR attention deficit hyperactivity[Title]) NOT rats[Title] NOT rat[Title] NOT dog[Title] NOT dogs[Title] NOT rabbits[Title] NOT rabbit[Title] NOT mice[Title]. We used Google Scholar to ascertain if any articles were missed in the PubMed, CENTRAL and PsycNet searches. We performed 2 searches in Google Scholar using different keywords (details in Supplement 2). For each search, we screened the first 100 articles to identify articles that were not found previously. We also examined all references from relevant review articles. 
We considered peer-reviewed, published studies (including studies published online ahead of print) in English (or translated into English) from January 1, 1990, to July 15, 2019. We excluded all studies published as editorials or commentaries. We excluded treatment trials, studies with less than 20 participants, studies where all participants were $\geq 50$ years old (due to the impact of aging on urinary symptoms), studies reporting only nocturnal enuresis, and studies in which it was not possible to separate the results for daytime incontinence from those for nocturnal enuresis/nighttime incontinence.

We excluded LUTS associated with physical trauma, cancer, sexually-transmitted infection, congenital malformation of the urinary tract, post-operative disorders, those related primarily to pregnancy, dysfunction secondary to aging, and medications that promote urination/water retention. We excluded outcomes associated with kidney malfunction. Observational studies were included in the review (cohort studies, case-control studies, and cross-sectional studies). We did not include ecological, treatment, or case series studies.

\subsection{Data analysis}

For each study, we extracted the number of exposed and unexposed individuals with LUTS and ADHD to calculate the odds ratio. We excluded articles that did not provide the necessary data for meta-analysis. If multiple studies analyzed the same data, then we chose only one study. We performed meta-analyses using random-effects models and evaluated publication bias using funnel plots and applied Egger's test [16]. We used metafor package in $\mathrm{R}$ for the meta-analysis [17].

\section{Results}

We identified 117 articles published from January 1, 1990 to July 15, 2019 that met the inclusion criteria (Figure 2, Identification). After the review of titles, abstracts, and full texts, 17 articles were included in the qualitative and quantitative synthesis (Table 1). Of those articles, 5 had the required information for metaanalysis (Table 1). Urinary storage symptoms (urinary urgency, urinary frequency, daytime urinary incontinence (DUI)) and voiding problems were the most commonly reported LUTS that co-occur with psychiatric disorders. 
medRxiv preprint doi: https://doi.org/10.1101/2020.08.28.20183541; this version posted September 1, 2020. The copyright holder for this preprint (which was not certified by peer review) is the author/funder, who has granted medRxiv a license to display the preprint in perpetuity.

It is made available under a CC-BY-NC-ND 4.0 International license .

\subsection{Qualitative synthesis}

For the 17 articles eligible for qualitative synthesis, several reported that patients with ADHD have a higher incidence of LUTS compared to age- and sex-matched controls [6, 7]. In a study of 62 children (6-17 age range) with ADHD and 124 healthy controls, the mean total LUTS score (measured using the Urinary Tract Symptom Score, LUTTS) was $11.1 \pm 2.9$ in patients with ADHD and $3.2 \pm 1.3$ in controls $(\mathrm{p}<0.001)$ [6]. LUTTS contains 14 questions, with the total score ranged between 0 and 56 [18]. Similar findings emerge from a study of 28 cases (23 boys and 5 girls; ages 6-12 years) and 22 controls using a modified Dysfunctional Voiding Symptom Scale (DVSS). The modified DVSS was designed to quantify voiding symptoms in children using 10 questions, scored on a 0 to 4 scale. In this study, the mean overall score for LUTS using the modified DVSS in boys with ADHD and controls was $14.83 \pm 3.68$ and $6.00 \pm 5.74(\mathrm{p}<$ 0.0005), respectively. Overall, children of both sexes with ADHD had statistically significant higher overall DVSS scores [7].

Multiple studies reported that in patients with LUTS there was a higher incidence of ADHD compared to matched controls [8, 9, 27, 19-26]. Joinson et al. conducted one of the largest population-based analyses of the psychological problems associated with daytime incontinence in children using the Avon Longitudinal Study of Parents and Children (ALSPAC) cohort [20]. ALSPAC is a large population-based longitudinal study of children born in the former county of Avon, England, during 1991 and 1992 [28]. A self-report questionnaire asked parents a set of questions about their child's toileting behavior. The Development and Well-Being Assessment (DAWBA) was also included in the questionnaire [28]. Among 8213 children (79 age range), 643 children (7.8\%) had daytime wetting. Children with daytime wetting also had a higher rate for each of the parent-reported psychological problems compared to children with no daytime wetting. The largest difference between those with daytime wetting and those without was in attention and activity problems $(24.8 \%)$.

Two large studies in Germany similarly reported a higher rate of ADHD among children with LUTS. In a school entry medical examination of 2,348 children in Saarbrücken county, parents completed a 32-item questionnaire regarding incontinence, oppositional defiant disorder, and ADHD symptoms [29]. Boys and 
medRxiv preprint doi: https://doi.org/10.1101/2020.08.28.20183541; this version posted September 1, 2020. The copyright holder for this preprint (which was not certified by peer review) is the author/funder, who has granted medRxiv a license to display the preprint in perpetuity.

It is made available under a CC-BY-NC-ND 4.0 International license .

girls had similar rates of daytime incontinence, and $10.3 \%$ of children with incontinence had ADHD. In another school entry medical examination of 1,391 children in the Saarpfalz Kreis county, ADHD symptoms (using the Child Behavior Checklist [30]) were more common in children with urinary incontinence than non-wetting children (16.8\% vs. $3.4 \%)$.

Additional support for the positive association between ADHD and LUTS comes from a large study in Sydney, Australia. In this population-based study of 2,856 children, urinary frequency and daytime incontinence were grouped into very mild, mild, moderate, and severe categories. Severe daytime urinary incontinence was positively associated with ADHD with an odds ratio of 4.8 (95\%CI, 2-11.9) [23].

In a urology clinic sample $(n=120)$, Yang et al. examined hyperactivity in children with untreated LUTS [25]. Boys with higher scores of ADHD hyperactive subtype had a higher DVSS score [31].

Multiple studies have analyzed a range of behavioral comorbidities, including ADHD, in children with LUTS who present at urology clinics. Of 600 children presenting to an outpatient urology clinic, $15.2 \%$ met the clinical cut-off for significant psychosocial difficulties utilizing parent report the Pediatric Symptom Checklist. ADHD was the most commonly reported disorder (14\%), followed by depression and anxiety [24]. In another study of 358 children (6 to 17 years old) with non-neurogenic lower urinary tract dysfunction, younger age was correlated with a higher LUTS score $(r=-0.34, p<0.0001$, measured using LUTTS) [21] and ADHD was the most prevalent psychiatric disorder (8.4\%). Schast et al. studied 351 voiding clinic patients at the Children's Hospital of Philadelphia, USA, and found that $25 \%$ were diagnosed with a mental or behavioral health problem, and, ADHD was the most commonly reported diagnosis (13\%) [22] a higher rate than a recent US national survey that reported 9.4\% ADHD prevalence [2]. In a study of 166 children referred to a specialized outpatient clinic, different subtypes of urinary incontinence reported different behavioral problems and psychiatric comorbidity; children with voiding postponement had the highest rates of psychiatric comorbidities, including ADHD [26].

Özen et al. studied the association between lower urinary tract dysfunction and psychiatric disorders in 156 children and highlights the importance of screening tests for psychological problems among children with LUTS. Among children with LUTS, ADHD was the most common psychiatric disorder (16.1\%). This study 
medRxiv preprint doi: https://doi.org/10.1101/2020.08.28.20183541; this version posted September 1, 2020. The copyright holder for this preprint (which was not certified by peer review) is the author/funder, who has granted medRxiv a license to display the preprint in perpetuity.

It is made available under a CC-BY-NC-ND 4.0 International license .

is one of the very few studies that include a subsample of individuals with OAB (76 children). $19.7 \%$ of children with $\mathrm{OAB}$ had ADHD [8]. In another study of OAB, Yousefichaijan et al. investigated the risk of ADHD in 92 children with $\mathrm{OAB}$ and 92 healthy controls [9]. The prevalence of ADHD among the cases was significantly higher than the controls $(35.9 \%$ vs. $19.6 \%$; $\mathrm{P}=0.021)$.

\subsection{Meta-analysis}

Our review yielded 5 articles that qualified for meta-analysis. The characteristics of these studies are present in Table 1. The odds ratio using random effect models for ADHD among individuals with LUTS was 2.99 (95\% CI: 1.13,7.88, P < 0.001; Figure 1).

The large value of Cochran's Q test, $\mathrm{I}^{2}$ index, and visual inspection of the funnel plot (Figure 2 and Figure S1) suggest a high heterogeneity between studies. The heterogeneity may be related to bias from publication, reporting, and selection, as supported by two studies plotting outside the funnel outline in the funnel plot.

\section{Discussion}

This systematic review and meta-analysis demonstrate a strong association between ADHD and LUTS. The odds ratio for ADHD amongst children with a LUTS diagnosis was 2.99 (95\% CI: 1.13,7.88, P < 0.001). Different subtypes of urinary incontinence demonstrated differences in behavioral problems and psychiatric comorbidity; however, multiple studies indicate that ADHD is the most common psychiatric disorder among children with LUTS and occurs at rates higher than expected based on population prevalence.

Although there were insufficient data for meta-analysis, multiple studies reported that the mean score for LUTS (measured via the LUTTS and DVSS) was significantly higher in patients with ADHD in comparison to controls, and the severity of ADHD was positively associated with the severity of LUTS. In addition, younger age in children was positively correlated with a higher LUTS score. We did not observe a consistent pattern for sex differences in LUTS across article reviews.

The present meta-analyses had several strengths and some limitations. This study is the first systematic review and meta-analysis analyzing the association between ADHD and LUTS in children. We included multiple case-control and cohort studies with a relatively large sample size and low risk of bias. However, 
medRxiv preprint doi: https://doi.org/10.1101/2020.08.28.20183541; this version posted September 1, 2020. The copyright holder for this preprint (which was not certified by peer review) is the author/funder, who has granted medRxiv a license to display the preprint in perpetuity.

It is made available under a CC-BY-NC-ND 4.0 International license .

only 5 studies were included in the meta-analysis; therefore, the potential effect of publication bias and small study effects should be considered when interpreting the results. Comparison of Cochran's Q test and $\mathrm{I}^{2}$ index suggested a high degree of heterogeneity in the studies. We believe that the leading cause of heterogeneity was the variation in the definition of LUTS and ADHD. Diagnostic criteria and definitions of LUTS and ADHD were not always consistent or clear across the studies. Some studies used a clinical diagnosis, while others measured LUTS and ADHD symptoms using standardized assessments. While the Egger test was not statistically significant ( $\mathrm{p}$-value $=0.50$ ), there were small numbers of studies, that reduced its power. With visual inspection of the funnel plot, it appears that smaller studies without statistically significant effects may not have been published.

In summary, our results indicate clinically significant associations between ADHD and LUTS in children. LUTS is a common disorder in children, and clinicians should be aware of this association because this can interfere with treatment or inform optimal treatments. In addition, the presence of ADHD may impact performance of behavioral therapies for LUTS. Our analyses also highlight a significant gap in the literature. Studies of LUTS in children ascertained for ADHD were rare. Additionally, there were no studies using national registers, in which there is potentially less ascertainment and confounding bias. Despite the significant associations between forms of LUTS and psychiatric disorders, the factors underlying the significant co-occurrence of these conditions remain mostly unidentified. We also know little about the direction of risk and impact on treatment. Undoubtedly, optimal treatment for LUTS needs to incorporate the psychiatric dimension, requiring a more precise understanding of these relationships. Understanding the causes of the observed relationships between ADHD and LUTS, biological or behavioral, is an important topic for future study.

\section{References}

1. Mohammadi MR, Zarafshan H, Khaleghi A, et al (2019) Prevalence of ADHD and Its Comorbidities in a Population-Based Sample. J Atten Disord. https://doi.org/10.1177/1087054719886372

2. Danielson ML, Bitsko RH, Ghandour RM, et al (2018) Prevalence of Parent-Reported ADHD 
medRxiv preprint doi: https://doi.org/10.1101/2020.08.28.20183541; this version posted September 1, 2020. The copyright holder for this preprint (which was not certified by peer review) is the author/funder, who has granted medRxiv a license to display the preprint in perpetuity.

It is made available under a CC-BY-NC-ND 4.0 International license .

Diagnosis and Associated Treatment Among U.S. Children and Adolescents, 2016. J Clin Child Adolesc Psychol 47:199-212. https://doi.org/10.1080/15374416.2017.1417860

3. American Psychiatric Association (2013) Diagnostic and statistical manual of mental disorders (5th ed.). https://doi.org/ttp://dx.doi.org/10.1176/appi.books.9780890425596.CautionaryStatement

4. Tistarelli N, Fagnani C, Troianiello M, et al (2020) The nature and nurture of ADHD and its comorbidities: A narrative review on twin studies. Neurosci Biobehav Rev 109:63-77.

https://doi.org/10.1016/j.neubiorev.2019.12.017

5. Gnanavel S, Sharma P, Kaushal P, Hussain S (2019) Attention deficit hyperactivity disorder and comorbidity: A review of literature. World J Clin Cases 7:2420-2426.

https://doi.org/10.12998/wjcc.v7.i17.2420

6. Burgu B, Aydogdu O, Gurkan K, et al (2011) Lower Urinary tract conditions in children with attention deficit hyperactivity disorder: Correlation of symptoms based on validated scoring systems. J Urol 185:663-668. https://doi.org/10.1016/j.juro.2010.09.116

7. Duel BP, Steinberg-Epstein R, Hill M, et al (2003) A survey of voiding dysfunction in children with attention deficit-hyperactivity disorder. J Urol 170:1521-1524.

https://doi.org/10.1097/01.ju.0000091219.46560.7b

8. Özen MA, Mutluer T, Necef I, et al (2019) The overlooked association between lower urinary tract dysfunction and psychiatric disorders: a short screening test for clinical practice. J Pediatr Urol. https://doi.org/10.1016/j.jpurol.2019.03.025

9. Yousefichaijan P, Sharafkhah M, Rafiei M, Salehi B (2016) Attention-deficit/hyperactivity disorder in children with overactive bladder; a case-control study. J Ren Inj Prev 5:193-199.

https://doi.org/10.15171/jrip.2016.41

10. Austin PF, Bauer SB, Bower W, et al (2016) The standardization of terminology of lower urinary tract function in children and adolescents: Update report from the standardization committee of the International Children's Continence Society. Neurourol Urodyn 35:471-481.

https://doi.org/10.1002/nau.22751 
11. Sampaio AS, Fraga LGA, Salomão BA, et al (2017) Are lower urinary tract symptoms in children associated with urinary symptoms in their mothers? J Pediatr Urol 13:269.e1-269.e6.

https://doi.org/10.1016/j.jpurol.2016.12.017

12. Vaz GT, Vasconcelos MM, Oliveira EA, et al (2012) Prevalence of lower urinary tract symptoms in school-age children. Pediatr Nephrol 27:597-603. https://doi.org/10.1007/s00467-011-2028-1

13. Franco I (2016) Overactive bladder in children. Nat Rev Urol 13:520-532.

https://doi.org/10.1038/nrurol.2016.152

14. Moher D, Liberati A, Tetzlaff J, Altman DG (2009) Preferred reporting items for systematic reviews and meta-analyses: the PRISMA statement. J Clin Epidemiol 62:1006-1012. https://doi.org/10.1016/j.jclinepi.2009.06.005

15. (2020) PROSPERO International prospective register of systematic reviews

16. Schwarzer G, Carpenter JR, Rücker G (2015) Meta-Analysis with R (Use R!), 1st ed. Springer

17. Viechtbauer W (2010) Conducting meta-analyses in R with the metafor. J Stat Softw 36:1-48. https://doi.org/10.18637/jss.v036.i03

18. Blaivas JG, Tsui JF, Mekel G, et al (2015) Validation of the lower urinary tract symptom score. Can J Urol 22:7952-7958

19. Von Gontard A, Moritz AM, Thome-Granz S, Freitag C (2011) Association of attention deficit and elimination disorders at school entry: A population based study. J Urol 186:2027-2032. https://doi.org/10.1016/j.juro.2011.07.030

20. Joinson C, Heron J, von Gontard A (2006) Psychological Problems in Children With Daytime Wetting. Pediatrics 118:1985-1993. https://doi.org/10.1542/peds.2006-0894

21. Oliver JL, Campigotto MJ, Coplen DE, et al (2013) Psychosocial comorbidities and obesity are associated with lower urinary tract symptoms in children with voiding dysfunction. J Urol 190:1511-1515. https://doi.org/10.1016/j.juro.2013.02.025

22. Schast AP, Zderic SA, Richter M, et al (2008) Quantifying demographic, urological and behavioral characteristics of children with lower urinary tract symptoms. J Pediatr Urol 4:127-133. 
medRxiv preprint doi: https://doi.org/10.1101/2020.08.28.20183541; this version posted September 1, 2020. The copyright holder for this preprint (which was not certified by peer review) is the author/funder, who has granted medRxiv a license to display the preprint in perpetuity.

It is made available under a CC-BY-NC-ND 4.0 International license .

https://doi.org/10.1016/j.jpurol.2007.10.007

23. Sureshkumar P, Jones M, Cumming R, Craig J (2009) A Population Based Study of 2,856 SchoolAge Children With Urinary Incontinence. J Urol 181:808-816.

https://doi.org/10.1016/j.juro.2008.10.044

24. Wolfe-Christensen C, Veenstra AL, Kovacevic L, et al (2012) Psychosocial difficulties in children referred to pediatric urology: A closer look. Urology 80:907-913.

https://doi.org/10.1016/j.urology.2012.04.077

25. Yang TK, Guo YJ, Chen SC, et al (2012) Correlation between symptoms of voiding dysfunction and attention deficit disorder with hyperactivity in children with lower urinary tract symptoms. $\mathbf{J}$ Urol 187:656-663. https://doi.org/10.1016/j.juro.2011.10.016

26. Zink S, Freitag CM, von Gontard A (2008) Behavioral Comorbidity Differs in Subtypes of Enuresis and Urinary Incontinence. J Urol 179:295-298. https://doi.org/10.1016/j.juro.2007.09.007

27. Sureshkumar P, Jones M, Caldwell PHY, Craig JC (2009) Risk Factors for Nocturnal Enuresis in School-Age Children. J Urol 182:2893-2899. https://doi.org/10.1016/j.juro.2009.08.060

28. Golding J, Pembrey M, Jones R (2001) ALSPAC-The Avon Longitudinal Study of Parents and Children. Paediatr Perinat Epidemiol 15:74-87

29. Niemczyk J, Equit M, Braun-Bither K, et al (2015) Prevalence of incontinence, attention deficit/hyperactivity disorder and oppositional defiant disorder in preschool children. Eur Child Adolesc Psychiatry 24:837-843. https://doi.org/10.1007/s00787-014-0628-6

30. Achenbach, Thomas M, Ruffle, Thomas M (2000) The Child Behavior Checklist and Related Forms for Assessing Behavioral/Emotional Problems and Competencies. Pediatr Rev 21:

31. Farhat W, Bägli DJ, Capolicchio G, et al (2000) The dysfunctional voiding scoring system: Quantitative standardization of dysfunctional voiding symptoms in children. J Urol 164:1011-1015. https://doi.org/10.1016/S0022-5347(05)67239-4

32. Niemczyk J, Equit M, Rieck K, et al (2018) EEG measurement of emotion processing in children with daytime urinary incontinence. Z Kinder Jugendpsychiatr Psychother 46:336-341. 
medRxiv preprint doi: https://doi.org/10.1101/2020.08.28.20183541; this version posted September 1, 2020. The copyright holder for this preprint

(which was not certified by peer review) is the author/funder, who has granted medRxiv a license to display the preprint in perpetuity.

It is made available under a CC-BY-NC-ND 4.0 International license .

https://doi.org/10.1024/1422-4917/a000563

33. Gor RA, Fuhrer J, Schober JM (2012) A retrospective observational study of enuresis, daytime voiding symptoms, and response to medical therapy in children with attention deficit hyperactivity disorder and autism spectrum disorder. J Pediatr Urol 8:314-317.

https://doi.org/10.1016/j.jpurol.2010.10.009

34. Spencer TJ, Biederman J, Mick E (2007) Attention-deficit/hyperactivity disorder: Diagnosis, lifespan, comorbidities, and neurobiology. J Pediatr Psychol 32:631-642.

https://doi.org/10.1093/jpepsy/jsm005

35. Kuizenga-Wessel S, Koppen IJN, Vriesman MH, et al (2018) Attention Deficit Hyperactivity Disorder and Functional Defecation Disorders in Children. J Pediatr Gastroenterol Nutr 66:244249. https://doi.org/10.1097/MPG.0000000000001695 
Figure 1. PRISMA details

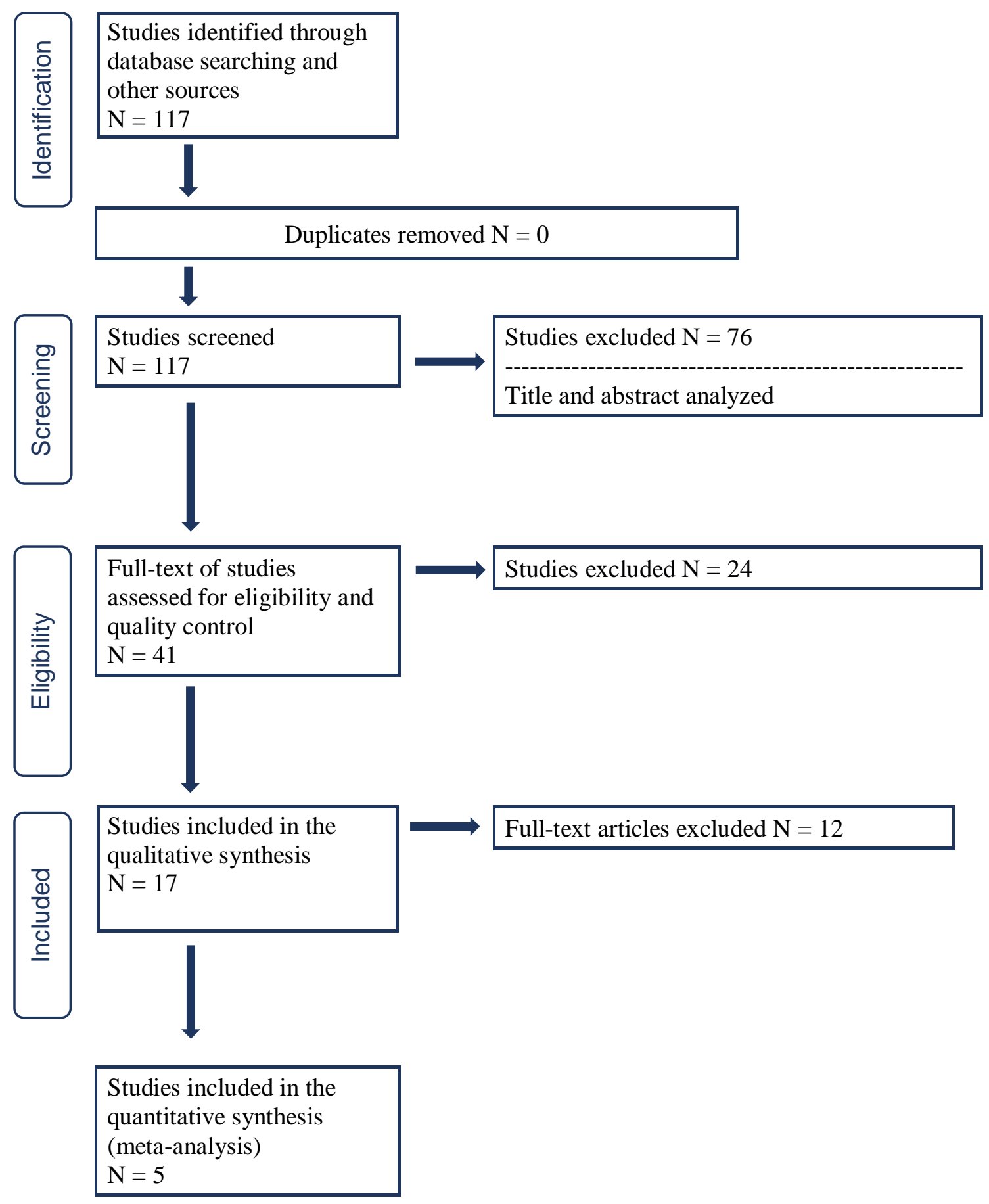


medRxiv preprint doi: https://doi.org/10.1101/2020.08.28.20183541; this version posted September 1, 2020. The copyright holder for this preprint (which was not certified by peer review) is the author/funder, who has granted medRxiv a license to display the preprint in perpetuity.

It is made available under a CC-BY-NC-ND 4.0 International license .

Figure 2. Forest plot for ADHD individuals with LUTS.

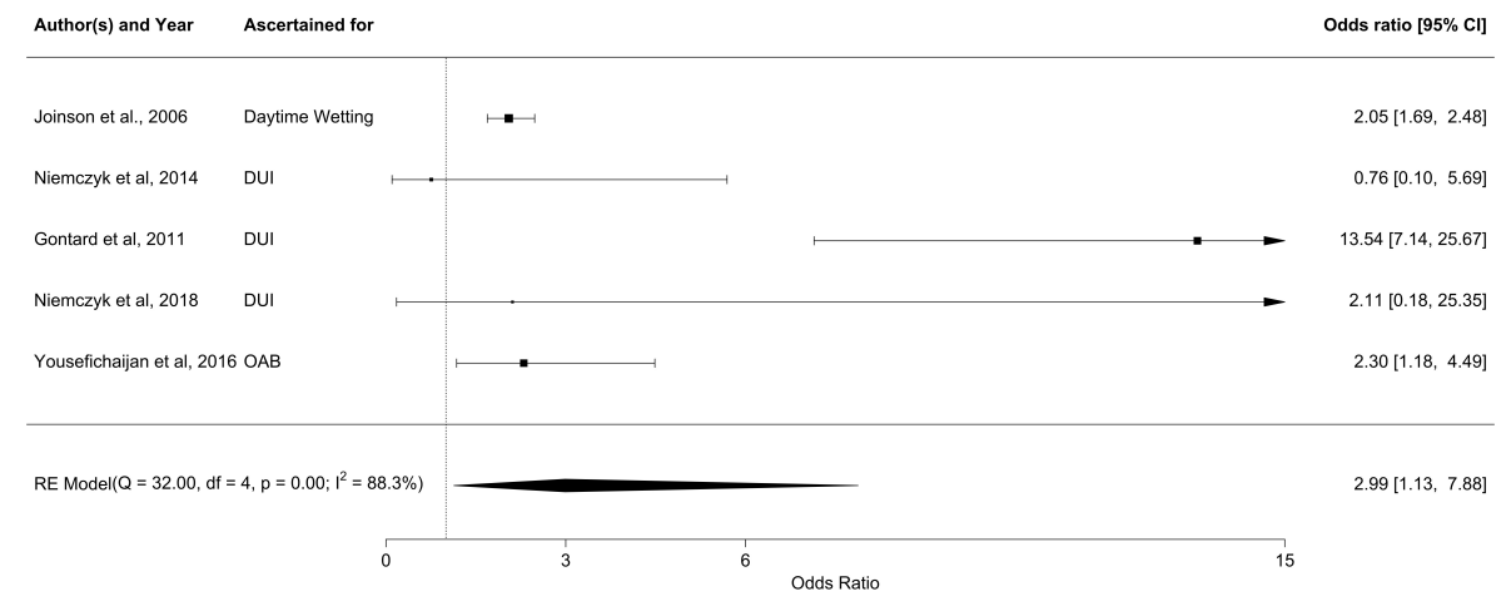

OAB: overactive bladder, DUI: Daytime urinary incontinence, LUTS: lower urinary tract symptoms. 
Table 1 Characteristics of included studies $(n=17)$

\begin{tabular}{|c|c|c|c|c|c|}
\hline Study & $\begin{array}{l}\text { LUTS Assessment } \\
\text { (scale) }\end{array}$ & $\begin{array}{l}\text { ADHD Assessment } \\
\text { Methods }\end{array}$ & Age & Notes & Study design \\
\hline Burgu et al. [6] & LUTSS $^{1}$ & CPRS-R $^{2}$ & $6-17$ & Age matched controls & Case-control \\
\hline Duel et al. [7] & DVSS $^{3}$ & $\begin{array}{l}\text { Clinical diagnosis at } \\
\text { Child Development } \\
\text { Center }\end{array}$ & $6-12$ & Controls from general pediatrics clinic & Case-control \\
\hline $\begin{array}{l}\text { Gontard et al. } \\
{[19]}\end{array}$ & Structured interview & $\begin{array}{l}\mathrm{CBCL}^{4} \text { and clinical } \\
\text { diagnosis }\end{array}$ & Mean: 6.22 & & $\begin{array}{l}\text { Cohort study, } \\
\text { county-based } \\
\text { population }\end{array}$ \\
\hline Gor et al. [33] & $\begin{array}{l}\text { Clinical examination } \\
\text { for daytime voiding } \\
\text { symptoms }\end{array}$ & Clinical diagnosis & Mean: 8.6 & & $\begin{array}{l}\text { Retrospective } \\
\text { observational } \\
\text { study }\end{array}$ \\
\hline $\begin{array}{l}\text { Joinson et al. } \\
{[20]}\end{array}$ & Parent report & DAWBA $^{5}$ & $7-9$ & Parents completed a postal questionnaire & $\begin{array}{l}\text { Population- } \\
\text { based } \\
\text { longitudinal } \\
\text { study }\end{array}$ \\
\hline $\begin{array}{l}\text { Niemczyk et. al } \\
{[29]}\end{array}$ & Parent report & Parent report & $4-8$ & & $\begin{array}{l}\text { Cross-sectional } \\
\text { study }\end{array}$ \\
\hline $\begin{array}{l}\text { Niemczyk et al. } \\
{[32]}\end{array}$ & $\begin{array}{l}\text { Clinical incontinence } \\
\text { examination }\end{array}$ & $\mathrm{CBCL}^{4}$ & $5-13$ & Emotion processing in children with DUI & Case-control \\
\hline Oliver et al. [21] & LUTSS $^{1}$ & Parent report & $6-17$ & & $\begin{array}{l}\text { Cross-sectional } \\
\text { study }\end{array}$ \\
\hline Özen et al. [8] & VDSS $^{6}$ & $\begin{array}{l}\text { Clinical diagnosis by } \\
\text { child psychiatrist }\end{array}$ & 6-18 & Case only & $\begin{array}{l}\text { Retrospective } \\
\text { observational } \\
\text { study }\end{array}$ \\
\hline Schast et al. [22] & PLUSS $^{7}$ & Parent report & $5-17$ & & $\begin{array}{l}\text { Cross-sectional } \\
\text { study }\end{array}$ \\
\hline $\begin{array}{l}\text { Sureshkumar et } \\
\text { al. [23] }\end{array}$ & $\begin{array}{l}\text { Parent report } \\
\text { (validated) }\end{array}$ & Parent report (validated) & Mean age: 7.3 & & $\begin{array}{l}\text { Cross-sectional } \\
\text { study }\end{array}$ \\
\hline $\begin{array}{l}\text { Kuizenga- } \\
\text { Wessel et al. } \\
{[35]}\end{array}$ & \begin{tabular}{|l} 
Standardized \\
questionnaires \\
including urinary \\
incontinence
\end{tabular} & $\mathrm{CBCL}^{4}$ and $\mathrm{VvGK}^{8}$ & Median: 9.5 & & $\begin{array}{l}\text { Cross-sectional } \\
\text { cohort study }\end{array}$ \\
\hline $\begin{array}{l}\text { Wolfe- } \\
\text { Christensen et al. } \\
{[24]}\end{array}$ & DVSS $^{3}$ & $\begin{array}{l}\mathrm{PSC}^{9} \text { and clinical } \\
\text { diagnosis by psychologist }\end{array}$ & $4-16$ & Retrospective chart review & $\begin{array}{l}\text { Cross-sectional } \\
\text { study }\end{array}$ \\
\hline Yang et al. [25] & $\begin{array}{l}\text { DVSS }^{3} \text {, Chinese } \\
\text { version }\end{array}$ & $\begin{array}{l}\text { SNAP-IV }{ }^{10}, \text { Chinese } \\
\text { version }\end{array}$ & $4-14$ & Case only & $\begin{array}{l}\text { Cross-sectional } \\
\text { study }\end{array}$ \\
\hline $\begin{array}{l}\text { Yousefichaijan } \\
\text { et al. [9] }\end{array}$ & \begin{tabular}{|l|} 
Clinical presentation, \\
imaging, and exclusion \\
of other causes of \\
voiding dysfunction, led \\
to overactive bladder \\
diagnosis
\end{tabular} & $\begin{array}{l}\text { CPRS-R and DSM IV- } \\
\text { TR criteria } \\
\end{array}$ & Mean 8.12 & & Case-control \\
\hline Zink et al. [26] & $\begin{array}{l}\text { Referred to a } \\
\text { specialized outpatient } \\
\text { clinic for elimination } \\
\text { disorders }\end{array}$ & $\mathrm{CBCL}^{4}$ and $\mathrm{ICD}-10$ & $5-16$ & & $\begin{array}{l}\text { Cross-sectional } \\
\text { study }\end{array}$ \\
\hline $\begin{array}{l}\text { Sureshkumar et } \\
\text { al. [27] }\end{array}$ & $\begin{array}{l}\text { Parent report } \\
\text { (validated) }\end{array}$ & Parent report (validated) & Mean 7.3 & & $\begin{array}{l}\text { Cross-sectional } \\
\text { study }\end{array}$ \\
\hline
\end{tabular}


medRxiv preprint doi: https://doi.org/10.1101/2020.08.28.20183541; this version posted September 1, 2020. The copyright holder for this preprint (which was not certified by peer review) is the author/funder, who has granted medRxiv a license to display the preprint in perpetuity.

Systematic Review and Meta-Analysis: Relationships Between Attention Deficit Hyperactivity Disorder and Daytime Urinary Symptoms in Children

\section{Supplements:}

- Supplement 1: PRISMA checklist

- Supplement 2: Database search strategy

- Figure S1. Funnel plot 


\section{Supplement 1: PRISMA 2009 checklist}

\begin{tabular}{|c|c|c|c|}
\hline Section/topic & $\#$ & Checklist item & $\begin{array}{l}\text { Reported on } \\
\text { page \# }\end{array}$ \\
\hline \multicolumn{4}{|l|}{ TITLE } \\
\hline Title & 1 & Identify the report as a systematic review, meta-analysis, or both. & 1 \\
\hline \multicolumn{4}{|l|}{ ABSTRACT } \\
\hline Structured summary & 2 & $\begin{array}{l}\text { Provide a structured summary including, as applicable: background; objectives; data sources; study eligibility criteria, participants, } \\
\text { and interventions; study appraisal and synthesis methods; results; limitations; conclusions and implications of key findings; } \\
\text { systematic review registration number. }\end{array}$ & 2 \\
\hline \multicolumn{4}{|l|}{ INTRODUCTION } \\
\hline Rationale & 3 & Describe the rationale for the review in the context of what is already known. & 3 \\
\hline Objectives & 4 & $\begin{array}{l}\text { Provide an explicit statement of questions being addressed with reference to participants, interventions, comparisons, outcomes, } \\
\text { and study design (PICOS). }\end{array}$ & 3 \\
\hline \multicolumn{4}{|l|}{ METHODS } \\
\hline $\begin{array}{l}\text { Protocol and } \\
\text { registration }\end{array}$ & 5 & $\begin{array}{l}\text { Indicate if a review protocol exists, if and where it can be accessed (e.g., Web address), and, if available, provide registration } \\
\text { information including registration number. }\end{array}$ & 5 \\
\hline Eligibility criteria & 6 & $\begin{array}{l}\text { Specify study characteristics (e.g., PICOS, length of follow-up) and report characteristics (e.g., years considered, language, } \\
\text { publication status) used as criteria for eligibility, giving rationale. }\end{array}$ & 6 \\
\hline Information sources & 7 & $\begin{array}{l}\text { Describe all information sources (e.g., databases with dates of coverage, contact with study authors to identify additional studies) in } \\
\text { the search and date last searched. }\end{array}$ & 5 \\
\hline Search & 8 & Present full electronic search strategy for at least one database, including any limits used, such that it could be repeated. & $\begin{array}{l}5 \\
\text { Supplement } 2\end{array}$ \\
\hline Study selection & 9 & $\begin{array}{l}\text { State the process for selecting studies (i.e., screening, eligibility, included in systematic review, and, if applicable, included in the } \\
\text { meta-analysis). }\end{array}$ & 5 \\
\hline $\begin{array}{l}\text { Data collection } \\
\text { process }\end{array}$ & 10 & $\begin{array}{l}\text { Describe method of data extraction from reports (e.g., piloted forms, independently, in duplicate) and any processes for obtaining } \\
\text { and confirming data from investigators. }\end{array}$ & 6 \\
\hline Data items & 11 & $\begin{array}{l}\text { List and define all variables for which data were sought (e.g., PICOS, funding sources) and any assumptions and simplifications } \\
\text { made. }\end{array}$ & 6 \\
\hline $\begin{array}{l}\text { Risk of bias in } \\
\text { individual studies }\end{array}$ & 12 & $\begin{array}{l}\text { Describe methods used for assessing risk of bias of individual studies (including specification of whether this was done at the study } \\
\text { or outcome level), and how this information is to be used in any data synthesis. }\end{array}$ & 6 \\
\hline Summary measures & 13 & State the principal summary measures (e.g., risk ratio, difference in means). & 6 \\
\hline Synthesis of results & 14 & $\begin{array}{l}\left.\text { Describe the methods of handling data and combining results of studies, if done, including measures of consistency (e.g., } \mathrm{I}^{2}\right) \text { for } \\
\text { each meta-analysis. }\end{array}$ & 6 \\
\hline
\end{tabular}




\begin{tabular}{|c|c|c|c|}
\hline Section/topic & $\#$ & Checklist item & $\begin{array}{l}\text { Reported on } \\
\text { page \# }\end{array}$ \\
\hline $\begin{array}{l}\text { Risk of bias across } \\
\text { studies }\end{array}$ & 15 & $\begin{array}{l}\text { Specify any assessment of risk of bias that may affect the cumulative evidence (e.g., publication bias, selective reporting within } \\
\text { studies). }\end{array}$ & 6 \\
\hline Additional analyses & 16 & $\begin{array}{l}\text { Describe methods of additional analyses (e.g., sensitivity or subgroup analyses, meta-regression), if done, indicating which were } \\
\text { pre-specified. }\end{array}$ & 6 \\
\hline \multicolumn{4}{|l|}{ RESULTS } \\
\hline Study selection & 17 & $\begin{array}{l}\text { Give numbers of studies screened, assessed for eligibility, and included in the review, with reasons for exclusions at each stage, } \\
\text { ideally with a flow diagram. }\end{array}$ & 6 , Figure 1 \\
\hline Study characteristics & 18 & $\begin{array}{l}\text { For each study, present characteristics for which data were extracted (e.g., study size, PICOS, follow-up period) and provide the } \\
\text { citations. }\end{array}$ & $\begin{array}{l}6-9 \\
\text { Table } 1\end{array}$ \\
\hline $\begin{array}{l}\text { Risk of bias within } \\
\text { studies }\end{array}$ & 19 & Present data on risk of bias of each study and, if available, any outcome level assessment (see item 12). & Figure 2 \\
\hline $\begin{array}{l}\text { Results of individual } \\
\text { studies }\end{array}$ & 20 & $\begin{array}{l}\text { For all outcomes considered (benefits or harms), present, for each study: (a) simple summary data for each intervention group } \\
\text { (b) effect estimates and confidence intervals, ideally with a forest plot. }\end{array}$ & 9 , Figure 2, \\
\hline Synthesis of results & 21 & Present results of each meta-analysis done, including confidence intervals and measures of consistency. & Figure 2 \\
\hline $\begin{array}{l}\text { Risk of bias across } \\
\text { studies }\end{array}$ & 22 & Present results of any assessment of risk of bias across studies (see Item 15). & $\begin{array}{l}9, \text { Figure } 2, \\
\text { Figure S1 }\end{array}$ \\
\hline Additional analysis & 23 & Give results of additional analyses, if done (e.g., sensitivity or subgroup analyses, meta-regression [see Item 16]). & \\
\hline \multicolumn{4}{|l|}{ DISCUSSION } \\
\hline Summary of evidence & 24 & $\begin{array}{l}\text { Summarize the main findings including the strength of evidence for each main outcome; consider their relevance to key groups } \\
\text { (e.g., healthcare providers, users, and policy makers). }\end{array}$ & $9-10$ \\
\hline Limitations & 25 & $\begin{array}{l}\text { Discuss limitations at study and outcome level (e.g., risk of bias), and at review-level (e.g., incomplete retrieval of identified } \\
\text { research, reporting bias). }\end{array}$ & 10 \\
\hline Conclusions & 26 & Provide a general interpretation of the results in the context of other evidence, and implications for future research. & $10-11$ \\
\hline \multicolumn{4}{|l|}{ FUNDING } \\
\hline Funding & 27 & $\begin{array}{l}\text { Describe sources of funding for the systematic review and other support (e.g., supply of data); role of funders for the systematic } \\
\text { review. }\end{array}$ & 3 \\
\hline \multicolumn{4}{|c|}{$\begin{array}{l}\text { From: Moher D, Liberati A, Tetzlaff J, Altman DG, The PRISMA Group (2009). Preferred Reporting Items for Systematic Reviews and Meta-Analyses: The PRISMA Statement. PLoS Med 6(7): e10000 } \\
\text { doi:10.1371/journal.pmed1000097 }\end{array}$} \\
\hline
\end{tabular}


medRxiv preprint doi: https://doi.org/10.1101/2020.08.28.20183541; this version posted September 1, 2020. The copyright holder for this preprint (which was not certified by peer review) is the author/funder, who has granted medRxiv a license to display the preprint in perpetuity.

It is made available under a CC-BY-NC-ND 4.0 International license .

\section{Supplement 2: Database search strategy}

\section{PubMed}

((urinary) OR (lower urinary tract) OR (overactive bladder) OR (bladder Pain Syndrome) OR (incontinence)) AND (attention deficit hyperactivity)) AND (urinary[Title] OR lower urinary tract[Title] OR overactive bladder[Title] OR bladder pain syndrome[Title] OR incontinence[Title] OR attention deficit hyperactivity[Title]) NOT rats[Title] NOT rat[Title] NOT dog[Title] NOT dogs[Title] NOT rabbits[Title] NOT rabbit[Title] NOT mice[Title]

Note: Similar strategies were used to search in PsycNet and Cochrane.

\section{Google Scholar}

We used Google Scholar to find articles that PubMed, PsycNet, and Cochrane searches might have missed. We performed 2 searches using the keywords below. For each search, we screened the first 100 results to find any relevant articles that PubMed, PsycNet, and Cochrane searches did not identify.

1. "attention deficit hyperactivity" "overactive bladder"

2. "attention deficit hyperactivity" "urinary" 
medRxiv preprint doi: https://doi.org/10.1101/2020.08.28.20183541; this version posted September 1 , 2020. The copyright holder for this preprint (which was not certified by peer review) is the author/funder, who has granted medRxiv a license to display the preprint in perpetuity.

\section{It is made available under a CC-BY-NC-ND 4.0 International license .}

Figure S1. Funnel plot

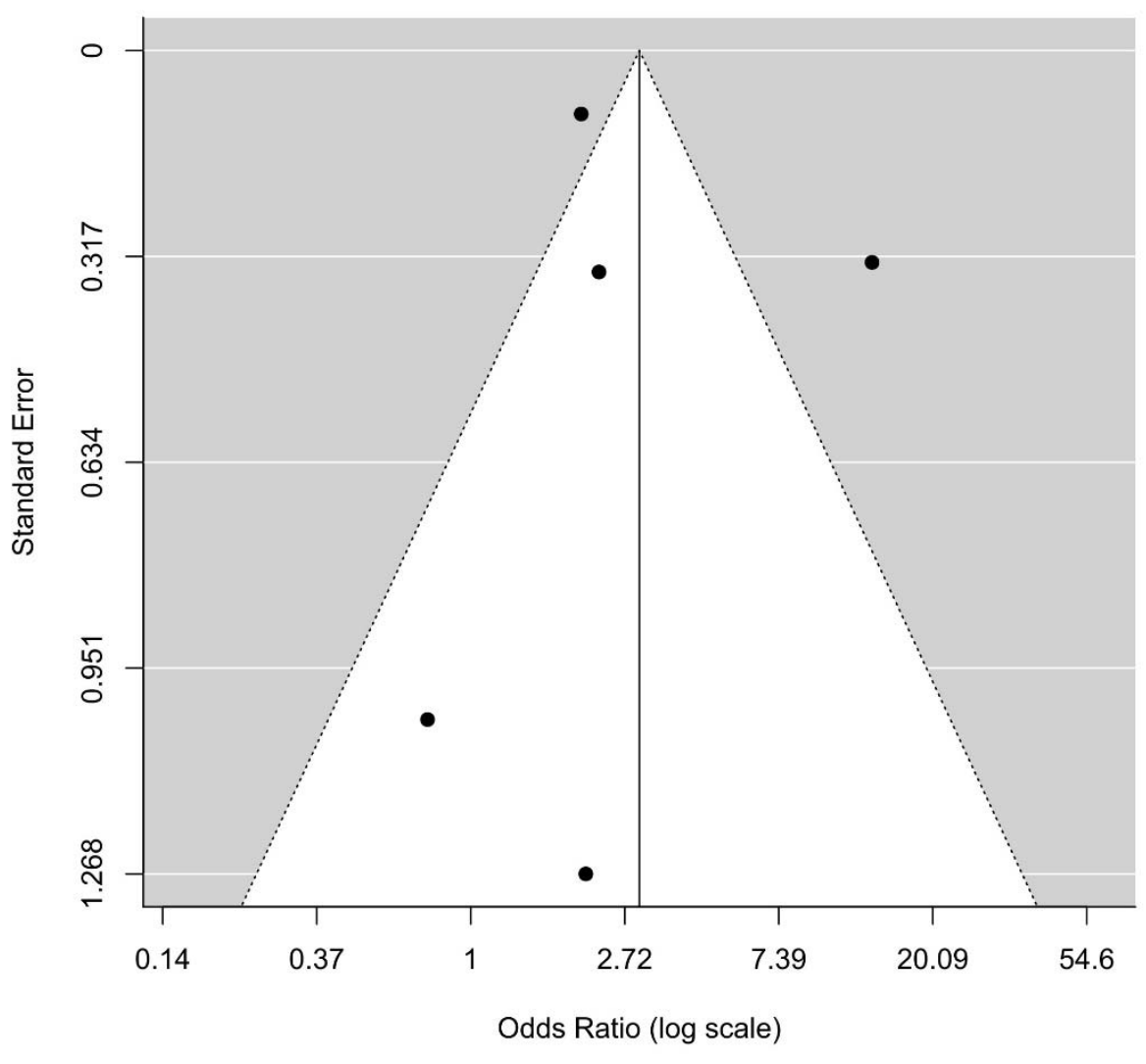


medRxiv preprint doi: https://doi.org/10.1101/2020.08.28.20183541; this version posted September 1, 2020. The copyright holder for this preprint (which was not certified by peer review) is the author/funder, who has granted medRxiv a license to display the preprint in perpetuity. It is made available under a CC-BY-NC-ND 4.0 International license .

\section{References:}

1. Burgu B, Aydogdu O, Gurkan K, et al. (2011) Lower Urinary tract conditions in children with attention deficit hyperactivity disorder: Correlation of symptoms based on validated scoring systems. J Urol 185:663-668. https://doi.org/10.1016/j.juro.2010.09.116

2. Duel BP, Steinberg-Epstein R, Hill M, et al. (2003) A survey of voiding dysfunction in children with attention deficit-hyperactivity disorder. J Urol 170:1521-1524.

https://doi.org/10.1097/01.ju.0000091219.46560.7b

3. Von Gontard A, Moritz AM, Thome-Granz S, Freitag C (2011) Association of attention deficit and elimination disorders at school entry: A population based study. J Urol 186:2027-2032. https://doi.org/10.1016/j.juro.2011.07.030

4. Gor RA, Fuhrer J, Schober JM (2012) A retrospective observational study of enuresis, daytime voiding symptoms, and response to medical therapy in children with attention deficit hyperactivity disorder and autism spectrum disorder. J Pediatr Urol 8:314-317. https://doi.org/10.1016/j.jpurol.2010.10.009

5. Joinson C, Heron J, von Gontard A (2006) Psychological Problems in Children With Daytime Wetting. Pediatrics 118:1985-1993. https://doi.org/10.1542/peds.2006-0894

6. Niemczyk J, Equit M, Braun-Bither K, et al. (2015) Prevalence of incontinence, attention deficit/hyperactivity disorder and oppositional defiant disorder in preschool children. Eur Child Adolesc Psychiatry 24:837-843. https://doi.org/10.1007/s00787-014-0628-6

7. Niemczyk J, Equit M, Rieck K, et al. (2018) EEG measurement of emotion processing in children with daytime urinary incontinence. Z Kinder Jugendpsychiatr Psychother 46:336-341. https://doi.org/10.1024/1422-4917/a000563

8. Oliver JL, Campigotto MJ, Coplen DE, et al. (2013) Psychosocial comorbidities and obesity are associated with lower urinary tract symptoms in children with voiding dysfunction. J Urol 190:15111515. https://doi.org/10.1016/j.juro.2013.02.025

9. Özen MA, Mutluer T, Necef I, et al. (2019) The overlooked association between lower urinary tract dysfunction and psychiatric disorders: a short screening test for clinical practice. J Pediatr Urol. https://doi.org/10.1016/j.jpurol.2019.03.025

10. Schast AP, Zderic SA, Richter M, et al. (2008) Quantifying demographic, urological and behavioral characteristics of children with lower urinary tract symptoms. J Pediatr Urol 4:127-133. https://doi.org/10.1016/j.jpurol.2007.10.007

11. Spencer TJ, Biederman J, Mick E (2007) Attention-deficit/hyperactivity disorder: Diagnosis, lifespan, comorbidities, and neurobiology. J Pediatr Psychol 32:631-642. https://doi.org/10.1093/jpepsy/jsm005

12. Sureshkumar P, Jones M, Cumming R, Craig J (2009) A Population Based Study of 2,856 School-Age Children With Urinary Incontinence. J Urol 181:808-816. https://doi.org/10.1016/j.juro.2008.10.044

13. Kuizenga-Wessel S, Koppen IJN, Vriesman MH, et al. (2018) Attention Deficit Hyperactivity Disorder and Functional Defecation Disorders in Children. J Pediatr Gastroenterol Nutr 66:244-249. https://doi.org/10.1097/MPG.0000000000001695

14. Wolfe-Christensen C, Veenstra AL, Kovacevic L, et al. (2012) Psychosocial difficulties in children referred to pediatric urology: A closer look. Urology 80:907-913.

https://doi.org/10.1016/j.urology.2012.04.077

15. Yang TK, Guo YJ, Chen SC, et al. (2012) Correlation between symptoms of voiding dysfunction and attention deficit disorder with hyperactivity in children with lower urinary tract symptoms. J Urol 187:656-663. https://doi.org/10.1016/j.juro.2011.10.016

16. Yousefichaijan P, Sharafkhah M, Rafiei M, Salehi B (2016) Attention-deficit/hyperactivity disorder in children with overactive bladder; a case-control study. J Ren Inj Prev 5:193-199. 
medRxiv preprint doi: https://doi.org/10.1101/2020.08.28.20183541; this version posted September 1, 2020. The copyright holder for this preprint

(which was not certified by peer review) is the author/funder, who has granted medRxiv a license to display the preprint in perpetuity.

It is made available under a CC-BY-NC-ND 4.0 International license .

https://doi.org/10.15171/jrip.2016.41

17. Zink S, Freitag CM, von Gontard A (2008) Behavioral Comorbidity Differs in Subtypes of Enuresis and Urinary Incontinence. J Urol 179:295-298. https://doi.org/10.1016/j.juro.2007.09.007

18. Sureshkumar P, Jones M, Caldwell PHY, Craig JC (2009) Risk Factors for Nocturnal Enuresis in SchoolAge Children. J Urol 182:2893-2899. https://doi.org/10.1016/j.juro.2009.08.060 